\title{
Experimental Investigation of the Machinability of Caldie Cold Work Tool Steel
}

\begin{abstract}
A. KALYON ${ }^{a, *}$ AND M.T. ÖZCAN ${ }^{b}$
${ }^{a}$ Karabuk University, Technology Faculty, Manufacturing Engineering, 78100 Karabuk, Turkey

${ }^{b}$ Karabuk University, Graduate School of Natural and Applied Sciences, 78100 Karabuk, Turkey

In this study, the effects of the types of cutting insert, cutting speed, and feed rate on the machinability of hardened Caldie cold work tool steel have been examined. Workpieces were applied to heat treatment having its hardness increased to $60 \mathrm{HRC}$ and then it was employed for hard turning. Experimental studies were employed by using two different types of cutting inserts (ceramic, CBN). Depth of cut was kept constant at $0.1 \mathrm{~mm}$. Three levels were determined both for the cutting speeds $(90,120,150 \mathrm{~m} / \mathrm{min})$, and for the feed rates $(0.05,0.1,0.15 \mathrm{~mm} / \mathrm{rev})$. Having $20 \mathrm{~cm}^{3}$ of chip volume machined from the hardened workpiece, wear at the cutting inserts were examined and average surface roughness of the workpieces were measured. Experimental design was performed by using Taguchi $L_{18}$ orthogonal arrays experiment set. Control factors for the ideal cutting conditions were determined by using of Taguchi technique. Effect of the control factors on the machining parameters was calculated using variance analysis (ANOVA). As a result of the study, feed rate was found to be the most effective machining parameter on the cutting force and on the average surface roughness. Furthermore, it was observed that wear occurred more in the cutting insert under the experimental conditions where the cutting speed and feed rate were used at high levels. Better average surface roughness and lesser tool wear were observed from the experimental studies in which CBN cutting tool was used, than from those in which ceramic cutting tool was used.
\end{abstract}

DOI: 10.12693/APhysPolA.135.601

PACS/topics: Caldie, surface roughness, cutting force, wear

\section{Introduction}

Cold work tool steels form a major class of tool steels, and have a wide field of use. These tool steels are used generally in the processes of forming, cutting, bending workpieces under temperatures lower than $200^{\circ} \mathrm{C}$. It is possible to deliver such features as high hardness and high corrosion resistance, depending on the alloying elements and carbon ratios it contains [1]. Caldie cold work tool steel among the cold work tool steels is a non-standard cold work tool steel being produced under patent by a Swedish tool steel producer, named Uddeholm Tooling. Since it is suitable for use at high hardness, it may yield a quite high compression strength. Its use at high hardness and toughness makes Caldie cold work tool steel preferable, particularly in high strength sheet metal applications, and also in the cutting, forming, cold forging, and powder pressing applications as well [2].

Hard turning is a manufacturing technique, used for achieving high surface quality in workpieces with hardness between 50 and $70 \mathrm{HRC}$ at low depth of cut by making use of cutting tools possessing high hardness and wear resistance [3]. Moreover, saving of time, good surface quality, elimination of deformities occurring in the piece due to heat, being a convenient manufacturing method, and not requiring an additional process, such as grinding, etc. may be listed as the advantages of the hard turning process. Hard turning technology is widely used in the

*corresponding author; e-mail: alikalyon@karabuk.edu.tr industry of manufacturing bearings, motion transmitting shafts, axles, and various engine parts $[4,5]$. It is important to determine the cutting parameters to be used in the application of hard turning technique. Cutting speed, feed rate, and depth of cut, which are chosen for the cutting parameters, are effective on the cutting forces and average surface roughness. There are studies included within the literature, in the course of which hard turning technique was applied successfully using $\mathrm{CBN}$ and PCBN cutting tools [6-9]. Hard turning applications may also be performed by making use of ceramic cutting inserts [10-12]. Some of the performed studies were reinforced by optimization and mathematical modelling applications [13-15]. Elbah et al. hard turned the AISI 4140 steel as a result of the study and reported that surface roughness were affected by maximum cutting depth and feed rate [16]. Gaitonde et al. hard turned AISI D2 cold work tool steels with ceramic inserts. They stated that the increased cutting depth increases cutting forces. They also noted that the low cutting depth had a positive effect on surface roughness [17]. Azizi et al. reported that as a result of statistical analysis, they found that the feed rate, workpiece hardness and cutting speed were effective parameters on surface roughness [18].

In this study, the machinability of Caldie cold work tool steel, which is frequently used in moldmaking, was investigated after hardening. Experiments were performed by making use of Taguchi $\mathrm{L}_{18}$ experiment design in order to reduce the costs, and to save time. Workpiece hardness was increased to $60 \mathrm{HRC}$, hard turned using ceramic and CBN cutting inserts. Effects of the feed rate and cutting speed on the average surface roughness and 
cutting forces were investigated. Furthermore, the wear mechanisms being occurred in the ceramic and CBN cutting inserts following hard turning were examined.

\section{Materials and equipments}

Caldie cold work tool steel, a non-standard cold-work tool steel being produced under patent by a Swedish tool steel producer, named Uddeholm Tooling, was used in this study as the workpiece. The chemical composition of the workpiece is shown in Table I. Workpiece were rough turned to the measure of $\varnothing 90 \times 110 \mathrm{~mm}^{3}$. As with the workpiece undergoing heat treatment at Böhler Uddeholm Çelik Sanayi ve Ticaret A.Ş., hardness thereof was increased up to $60 \mathrm{HRC}$.

TABLE I

Chemical composition of Caldie cold work tool steel.

\begin{tabular}{c|c|c|c|c|c|c}
\hline \hline Elements & $\mathrm{C}$ & $\mathrm{Si}$ & $\mathrm{Mn}$ & $\mathrm{Cr}$ & $\mathrm{Mo}$ & $\mathrm{V}$ \\
\hline wt\% & 0.7 & 0.2 & 0.5 & 5.0 & 2.3 & 0.5
\end{tabular}

TABLE II

Cutting parameters factors and levels. A - cutting insert type, B - cutting speed $(V)[\mathrm{m} / \mathrm{min}], \mathrm{C}$ - feed rate (f) $[\mathrm{mm} / \mathrm{rev}]$.

\begin{tabular}{c|c|c|c}
\hline \hline Factors & Level 1 & Level 2 & Level 3 \\
\hline A & ceramic & CBN & - \\
B & 90 & 120 & 150 \\
C & 0.05 & 0.1 & 0.15
\end{tabular}

Ceramic and CBN inserts used for turning operations were at the size and tolerance of DNGA150604, DNGA150404, respectively. Wear occurring in the cutting inserts were examined using scanning electron microscope (SEM). Workpiece at $60 \mathrm{HRC}$ hardness were hard turned at cutting length of $15 \mathrm{~mm}$ under dry condition. Turning experiments were performed by making use of the Taguchi $\mathrm{L}_{18}$ experiment set $\left(2^{1} \times 3^{2}\right)$. Since the measured cutting force and average surface roughness are required to be the least, "the smallest-the best" approach was adopted while determining the quality characteristic. In the course of the studies performed for determining the ideal machining level according to the Taguchi technique, first of all, the cutting parameters, being directly effective on the machinability criteria $F_{c}$ and $R_{a}$, were determined. For that purpose, three parameters were sequentially determined: A-cutting tool type, B-cutting speed $(\mathrm{m} / \mathrm{min})$ $(V)$, C-feed rate $(\mathrm{mm} / \mathrm{rev})(f)$. Outcomes of the experiments were evaluated by the graphics drawn up using the available data, and by the statistical analyses. Factors and levels of the turning experiments are shown in Table II.

\section{Results and discussion}

Table III shows the cutting force $\left(F_{c}\right)$ values obtained from the hard-turning experiments, and the $S / N$ ratios calculated according to "the smallest-the best" approach. In view of Table III, the lowest cutting force was obtained from the experiment with $\mathrm{A}_{2} \mathrm{~B}_{3} \mathrm{C}_{1}$, under the cutting conditions where CBN cutting insert was used with cutting speed of $150 \mathrm{~m} / \mathrm{min}$ and feed rate of $0.05 \mathrm{~mm} / \mathrm{rev}$.

$F_{c}, R_{a}$ results, and $\mathrm{S} / \mathrm{N}$ ratios.

\begin{tabular}{c|c|c|c|c|c|c|c|c}
\hline \hline Sq. & Experiment & $\begin{array}{c}\text { Cutting } \\
\text { insert type }\end{array}$ & $\begin{array}{c}V \\
{[\mathrm{~m} / \mathrm{min}]}\end{array}$ & $\begin{array}{c}f \\
{[\mathrm{~mm} / \mathrm{rev}]}\end{array}$ & $\begin{array}{c}F_{c} \\
{[\mathrm{~N}]}\end{array}$ & $\begin{array}{c}F_{c} \mathrm{~S} / \mathrm{N} \\
{[\mathrm{dB}]}\end{array}$ & $\begin{array}{c}R_{a} \\
{[\mu \mathrm{m}]}\end{array}$ & $\begin{array}{c}R_{a} \mathrm{~S} / \mathrm{N} \\
{[\mathrm{dB}]}\end{array}$ \\
\hline 1 & $\mathrm{~A}_{1} \mathrm{~B}_{1} \mathrm{C}_{1}$ & ceramic & 90 & 0.05 & 142.84 & -43.09 & 0.272 & 11.31 \\
2 & $\mathrm{~A}_{1} \mathrm{~B}_{1} \mathrm{C}_{2}$ & ceramic & 90 & 0.1 & 176.76 & -44.94 & 0.334 & 9.53 \\
3 & $\mathrm{~A}_{1} \mathrm{~B}_{1} \mathrm{C}_{3}$ & ceramic & 90 & 0.15 & 267.2 & -48.53 & 0.498 & 6.05 \\
4 & $\mathrm{~A}_{1} \mathrm{~B}_{2} \mathrm{C}_{1}$ & ceramic & 120 & 0.05 & 139.06 & -42.86 & 0.236 & 12.54 \\
5 & $\mathrm{~A}_{1} \mathrm{~B}_{2} \mathrm{C}_{2}$ & ceramic & 120 & 0.1 & 156.6 & -43.89 & 0.311 & 10.14 \\
6 & $\mathrm{~A}_{1} \mathrm{~B}_{2} \mathrm{C}_{3}$ & ceramic & 120 & 0.15 & 226.11 & -47.08 & 0.467 & 6.61 \\
7 & $\mathrm{~A}_{1} \mathrm{~B}_{3} \mathrm{C}_{1}$ & ceramic & 150 & 0.05 & 104.18 & -40.35 & 0.199 & 14.02 \\
8 & $\mathrm{~A}_{1} \mathrm{~B}_{3} \mathrm{C}_{2}$ & ceramic & 150 & 0.1 & 124.93 & -41.93 & 0.301 & 10.42 \\
9 & $\mathrm{~A}_{1} \mathrm{~B}_{3} \mathrm{C}_{3}$ & ceramic & 150 & 0.15 & 193.31 & -45.72 & 0.417 & 7.59 \\
10 & $\mathrm{~A}_{2} \mathrm{~B}_{1} \mathrm{C}_{1}$ & $\mathrm{CBN}$ & 90 & 0.05 & 139.68 & -42.90 & 0.251 & 12 \\
11 & $\mathrm{~A}_{2} \mathrm{~B}_{1} \mathrm{C}_{2}$ & $\mathrm{CBN}$ & 90 & 0.1 & 164.64 & -44.33 & 0.312 & 10.11 \\
12 & $\mathrm{~A}_{2} \mathrm{~B}_{1} \mathrm{C}_{3}$ & $\mathrm{CBN}$ & 90 & 0.15 & 226.58 & -47.10 & 0.424 & 7.45 \\
13 & $\mathrm{~A}_{2} \mathrm{~B}_{2} \mathrm{C}_{1}$ & $\mathrm{CBN}$ & 120 & 0.05 & 128.57 & -42.18 & 0.237 & 12.50 \\
14 & $\mathrm{~A}_{2} \mathrm{~B}_{2} \mathrm{C}_{2}$ & $\mathrm{CBN}$ & 120 & 0.1 & 153.8 & -43.73 & 0.288 & 10.81 \\
15 & $\mathrm{~A}_{2} \mathrm{~B}_{2} \mathrm{C}_{3}$ & $\mathrm{CBN}$ & 120 & 0.15 & 216.49 & -46.70 & 0.397 & 8.02 \\
16 & $\mathrm{~A}_{2} \mathrm{~B}_{3} \mathrm{C}_{1}$ & $\mathrm{CBN}$ & 150 & 0.05 & 96.78 & -39.71 & 0.196 & 14.15 \\
17 & $\mathrm{~A}_{2} \mathrm{~B}_{3} \mathrm{C}_{2}$ & $\mathrm{CBN}$ & 150 & 0.1 & 107.68 & -40.64 & 0.264 & 11.56 \\
18 & $\mathrm{~A}_{2} \mathrm{~B}_{3} \mathrm{C}_{3}$ & $\mathrm{CBN}$ & 150 & 0.15 & 182.2 & -45.21 & 0.402 & 7.91
\end{tabular}


Cutting force was measured to be $96.78 \mathrm{~N}$. The experimental condition, under which the highest cutting force was obtained, was in the form of $\mathrm{A}_{1} \mathrm{~B}_{1} \mathrm{C}_{3}$, under the working conditions where ceramic cutting insert was used with cutting speed of $90 \mathrm{~m} / \mathrm{min}$ and feed rate of $0.15 \mathrm{~mm} / \mathrm{rev}$. In this case, cutting force was measured as $267.2 \mathrm{~N}$. The lowest average surface roughness was obtained from the experiment with $\mathrm{A}_{2} \mathrm{~B}_{3} \mathrm{C}_{1}$. Under the machining conditions where $\mathrm{CBN}$ cutting insert was used with cutting speed of $150 \mathrm{~m} / \mathrm{min}$ and feed rate of 0.05 $\mathrm{mm} / \mathrm{rev}$, average surface roughness was measured to be $0.196 \mu \mathrm{m}$. The experimental condition, under which the highest average surface roughness value was obtained, was in the experiment with $\mathrm{A}_{1} \mathrm{~B}_{1} \mathrm{C}_{3}$. In the experiment where ceramic cutting insert was used with cutting speed of $90 \mathrm{~m} / \mathrm{min}$ and feed rate of $0.15 \mathrm{~mm} / \mathrm{rev}$, average surface roughness was measured as $0.498 \mu \mathrm{m}$.
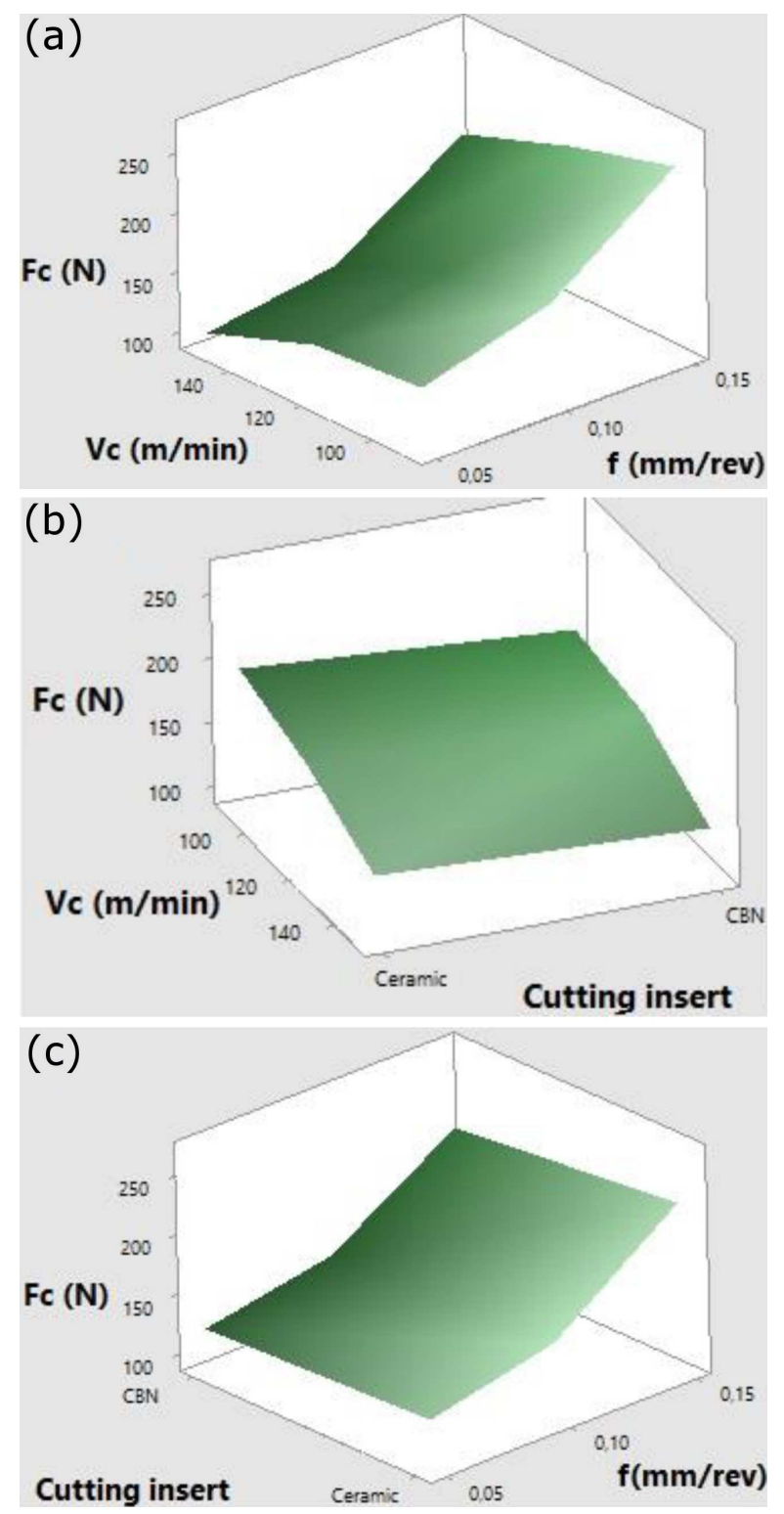

Fig. 1. Effect of cutting parameters on cutting forces.
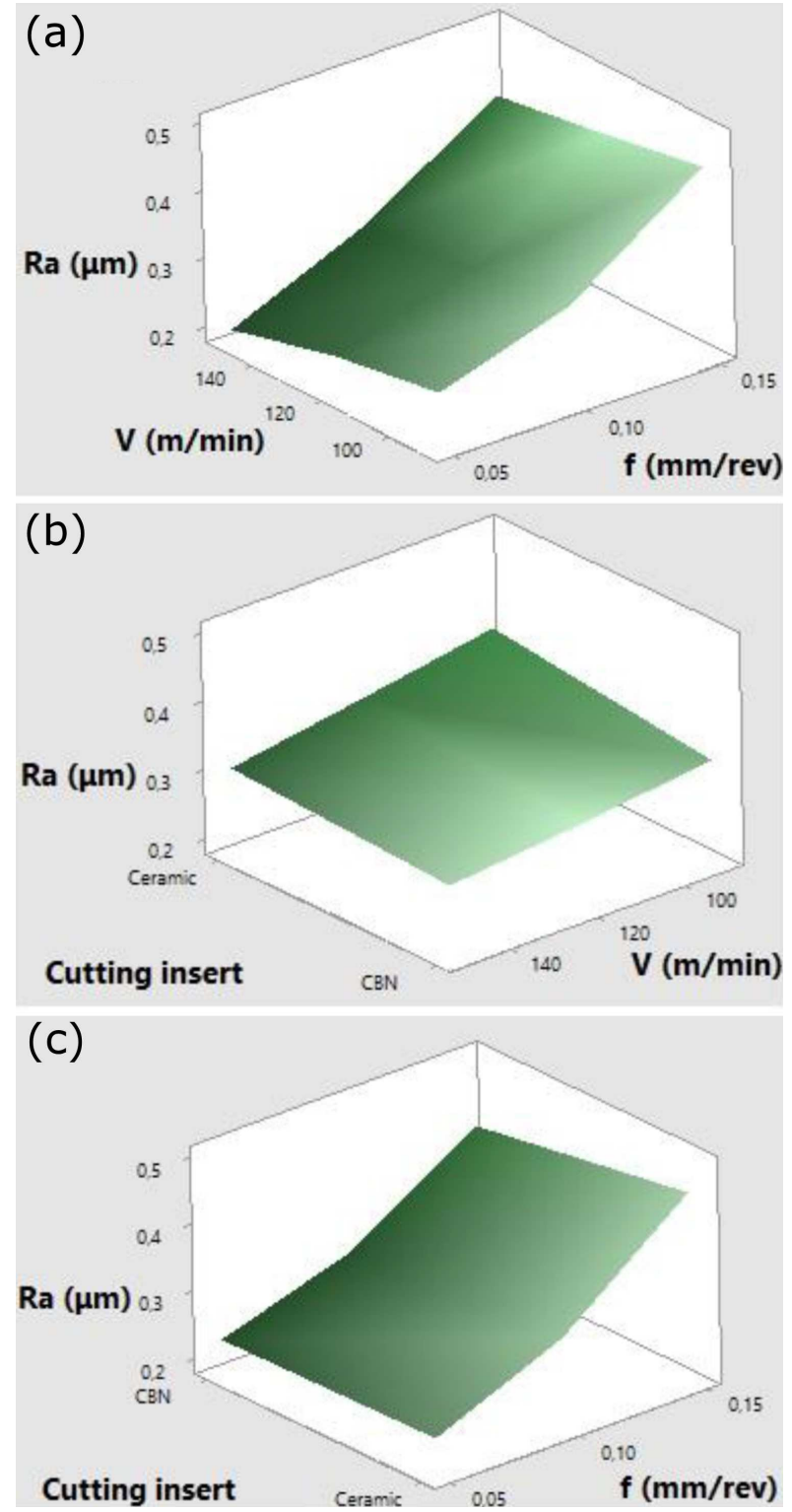

Fig. 2. Effect of cutting parameters on surface roughness.

The variance of the cutting force according to the cutting parameters in the course of hard turning is shown graphically in Fig. 1. In view of Fig. 1a, it is seen that, with increase in the cutting speed, cutting force decreases. The cause of the decrease in the cutting force with the increase in the cutting speed is that the increase in the heat at the first deformation area, caused by the increase in the cutting speed, facilitates the chip formation [19]. Cutting force increases depending on the increase in the feed rate. Since the increase in the feed rate causes the enlargement of the unformed chip, the force needed for the deformation of the emanated chip increases, and such increased feed rate causes the increase in the cutting force in the meantime [19]. In views of Fig. $1 b$ and $c$, the type of the cutting insert seems to have a significant effect on the cutting force. As an outcome of the experiments, the factors and levels found 
to be affecting the cutting force $\left(F_{c}\right)$ mostly are of the type of the cutting insert (2), cutting speed (3), and feed rate (1). Performing variance analysis (ANOVA) brings along more substantial outcomes in order to definitely determine the contribution of these factors in the cutting force. As an outcome of ANOVA analysis, the factors effective on the cutting force were found as feed rate $74.5 \%$, cutting speed $21.61 \%$, and type of cutting insert $1.89 \%$, respectively.

The average surface roughness values obtained from the experimental study are shown in Fig. 2. In view of Fig. 2a, it seems that with increase in the cutting force, the average surface roughness increases. Facilitation of the deformation process at the cutting zone is a consequence of the rapidly rising temperature caused by the increase in the cutting speed, and easy deformation of the workpiece in the cutting edge and insert radius [20]. It is seen that the cutting forces increase with increase in the feed rate. Increase in the feed rate causes dislocation accumulations at the parts near the turned surface, depending on the cutting parameters. Occurrence of such dislocation accumulations causes the hardening of the matrix, and that of the material as well. This leads to high surface roughness at higher feed rates [20]. In view of Fig. $2 b$ and $c$, the effect of the type of cutting insert on the surface roughness is limited. It is seen that the average surface roughness value varies depending on the cutting speed and feed rate. As an outcome of the Taguchi method, it is found that the factors and levels affecting the surface roughness $\left(R_{a}\right)$ the most are the feed rate (1), cutting speed (3), and the type of the cutting insert (2). Following the ANOVA analysis, the factor mostly effective on the average surface roughness was found to be the feed rate by $89.32 \%$. Cutting speed was calculated to be $5.68 \%$.

In order to examine the wear behaviors of the cutting inserts due to hard turning of workpiece, the tools were machined to $20 \mathrm{~cm}^{3}$ of chip volume. Cutting depth was kept constant at $0.1 \mathrm{~mm}$ for the experimental conditions. Average surface roughness $R_{a}$ results and the $\mathrm{S} / \mathrm{N}$ ratios were calculated by means of "the smallest-the best" approach and are shown in Table IV.

In Table IV, the lowest surface roughness was obtained as $0.592 \mu \mathrm{m}$ from the experiment with the $\mathrm{A}_{2} \mathrm{~B}_{1} \mathrm{C}_{1}$. The lowest surface roughness was obtained under the experimental condition where CBN cutting tool was used, the cutting speed was $90 \mathrm{~m} / \mathrm{min}$, and the feed rate was $0.05 \mathrm{~mm} / \mathrm{rev}$. The highest surface roughness, on the other hand, was obtained under the condition of the experiment with $\mathrm{A}_{1} \mathrm{~B}_{3} \mathrm{C}_{3}$. Under this experimental condition, where ceramic cutting insert was used with cutting speed of $150 \mathrm{~m} / \mathrm{min}$ and feed rate $0.15 \mathrm{~mm} / \mathrm{rev}, 2.692 \mu \mathrm{m}$ of surface roughness was obtained.

In view of the effect of the average surface roughness given in Fig. 3a on the cutting parameters, it is seen that the surface roughness increases with the increase in the cutting speed. The increase in the cutting speed increases the tool wear. Since the worn cutting inserts
Average surface roughness results.

\begin{tabular}{c|c|c|c|c|c|c}
\hline \hline Sq. & Experiment & $\begin{array}{c}\text { Cutting } \\
\text { insert } \\
\text { type }\end{array}$ & $\begin{array}{c}\text { Cutting } \\
\text { speed } \\
{[\mathrm{m} / \mathrm{min}]}\end{array}$ & $\begin{array}{c}\text { Feed } \\
\text { rate } \\
{[\mathrm{mm} / \mathrm{rev}]}\end{array}$ & $\begin{array}{c}R_{a} \\
{[\mu \mathrm{m}]}\end{array}$ & $\begin{array}{c}\mathrm{S} / \mathrm{N} \\
{[\mathrm{dB}]}\end{array}$ \\
\hline 1 & $\mathrm{~A}_{1} \mathrm{~B}_{1} \mathrm{C}_{1}$ & ceramic & 90 & 0.05 & 0.982 & 0.15 \\
2 & $\mathrm{~A}_{1} \mathrm{~B}_{1} \mathrm{C}_{2}$ & ceramic & 90 & 0.1 & 1.407 & -2.96 \\
3 & $\mathrm{~A}_{1} \mathrm{~B}_{1} \mathrm{C}_{3}$ & ceramic & 90 & 0.15 & 2.187 & -6.79 \\
4 & $\mathrm{~A}_{1} \mathrm{~B}_{2} \mathrm{C}_{1}$ & ceramic & 120 & 0.05 & 1.054 & -0.45 \\
5 & $\mathrm{~A}_{1} \mathrm{~B}_{2} \mathrm{C}_{2}$ & ceramic & 120 & 0.1 & 1.468 & -3.33 \\
6 & $\mathrm{~A}_{1} \mathrm{~B}_{2} \mathrm{C}_{3}$ & ceramic & 120 & 0.15 & 2.228 & -6.95 \\
7 & $\mathrm{~A}_{1} \mathrm{~B}_{3} \mathrm{C}_{1}$ & ceramic & 150 & 0.05 & 1.297 & -2.25 \\
8 & $\mathrm{~A}_{1} \mathrm{~B}_{3} \mathrm{C}_{2}$ & ceramic & 150 & 0.1 & 1.807 & -5.13 \\
9 & $\mathrm{~A}_{1} \mathrm{~B}_{3} \mathrm{C}_{3}$ & ceramic & 150 & 0.15 & 2.692 & -8.60 \\
10 & $\mathrm{~A}_{2} \mathrm{~B}_{1} \mathrm{C}_{1}$ & CBN & 90 & 0.05 & 0.592 & 4.55 \\
11 & $\mathrm{~A}_{2} \mathrm{~B}_{1} \mathrm{C}_{2}$ & CBN & 90 & 0.1 & 0.661 & 3.59 \\
12 & $\mathrm{~A}_{2} \mathrm{~B}_{1} \mathrm{C}_{3}$ & CBN & 90 & 0.15 & 1.533 & -3.71 \\
13 & $\mathrm{~A}_{2} \mathrm{~B}_{2} \mathrm{C}_{1}$ & $\mathrm{CBN}$ & 120 & 0.05 & 0.791 & 2.03 \\
14 & $\mathrm{~A}_{2} \mathrm{~B}_{2} \mathrm{C}_{2}$ & $\mathrm{CBN}$ & 120 & 0.1 & 0.829 & 1.62 \\
15 & $\mathrm{~A}_{2} \mathrm{~B}_{2} \mathrm{C}_{3}$ & CBN & 120 & 0.15 & 1.536 & -3.72 \\
16 & $\mathrm{~A}_{2} \mathrm{~B}_{3} \mathrm{C}_{1}$ & CBN & 150 & 0.05 & 0.925 & 0.67 \\
17 & $\mathrm{~A}_{2} \mathrm{~B}_{3} \mathrm{C}_{2}$ & CBN & 150 & 0.1 & 1.018 & -0.15 \\
18 & $\mathrm{~A}_{2} \mathrm{~B}_{3} \mathrm{C}_{3}$ & $\mathrm{CBN}$ & 150 & 0.15 & 2.626 & -8.38 \\
& & & & & &
\end{tabular}

cause a poor surface roughness, increase in the cutting speed affects the surface roughness adversely. In view of Fig. 3b and c, it is seen that better surface roughness values were obtained by means of $\mathrm{CBN}$ cutting insert. It is known that CBN cutting inserts are more resistant against higher cutting temperatures and forces. Furthermore, CBN is the only cutting tool material that may substitute the conventionally used grinding methods. More ductile steels below 45 HRC contain higher ratio of ferrite, which has a negative effect on the corrosion strength of CBN.

Figure 3 shows effect of cutting parameters on tool wear. It is seen that the more the cutting speed increases, the more the cutting tools wear. For the depth of cut is 0.1 , wear occurred at the nose of insert. Feed rate is another parameter that similarly accelerates the wear in the cutting tool. In view of the average surface roughness values shown in Fig. 3 and Table IV, it is seen that $\mathrm{CBN}$ cutters have a better machining performance and are more resistant to wear. SEM image of the worn cutting insert after the hard turning by $150 \mathrm{~m} / \mathrm{min}$ of cutting speed and $0.15 \mathrm{~mm} / \mathrm{rev}$ of feed rate with ceramic cutting insert is seen in Fig. 4a. In view of Fig. 4a, nose wear is seen to have occurred in the cutting insert. High cutting speed brings about excess temperature increase in the cutting insert. This condition causes the cutting insert wear more. In Fig. 4b it is shown that the wear mechanisms occurred in the ceramic cutting insert after the hard turning process performed by CBN cutting insert employed with cutting speed of $150 \mathrm{~m} / \mathrm{min}$ and feed rate of $0.15 \mathrm{~mm} / \mathrm{rev}$. Nose wear occurred on CBN cutting insert, just like on the ceramic cutting insert. Furthermore, there were particles from the workpiece seen 

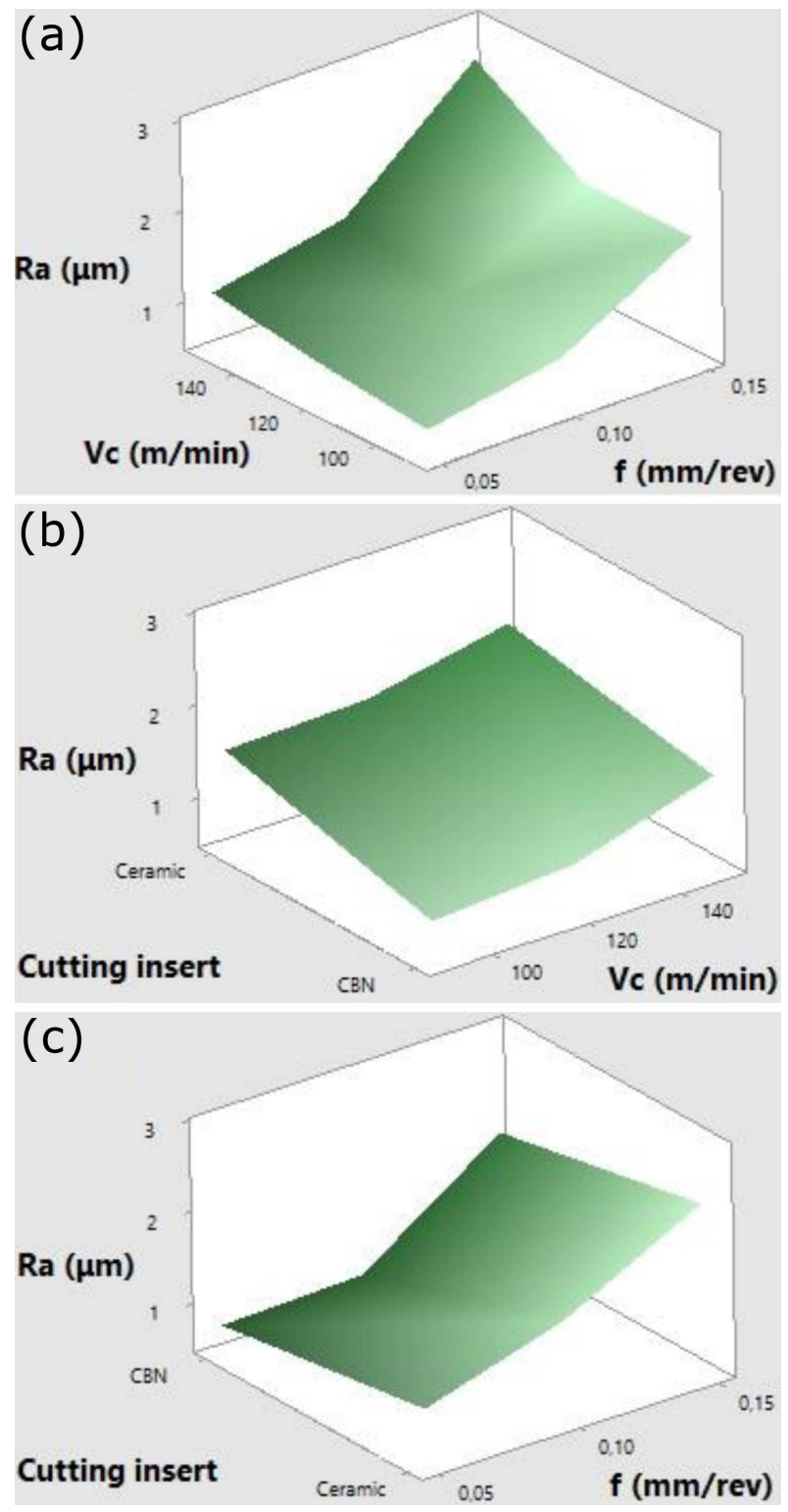

Fig. 3. Effect of cutting parameters on average surface roughness after machined $20 \mathrm{~cm}^{3}$ of chip volume.

to have adhered into the nose section of the cutting insert [20]. The factors and levels found to be the most effective for the surface roughness $R_{a}$ as an outcome of the Taguchi method are discerned as the type of the cutting insert (2), cutting speed (1), and the feed rate (1). The factors found to be with effective average surface roughness are, successively, the feed rate with $64.3 \%$, the type of the cutting insert with $16.29 \%$, and the cutting speed with $11.77 \%$, respectively.

\section{Conclusion}

Results of the study are: increase in the feed rate increases the cutting force, increase in the cutting speed decreases the cutting force, the average surface roughness values increase with the increases in the feed rate,
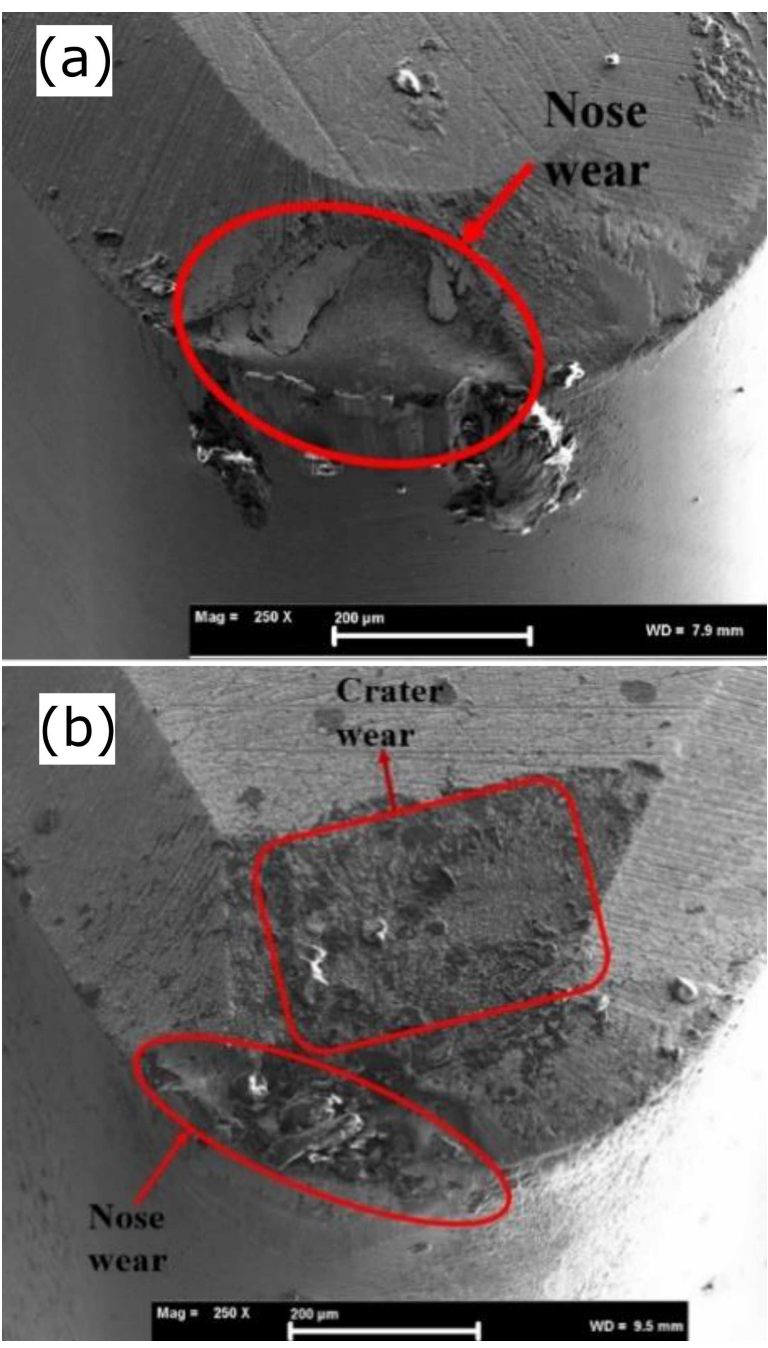

Fig. 4. SEM image of worn inserts: (a) ceramic, (b) CBN.

and increase in the cutting speed brings along better average surface roughness values. The results of the cutting insert wear experiments have revealed that feed rate causes more wear in the cutting insert, and high average surface roughness. Since the increasing cutting speed is a factor controlling the increase of temperature at the cutting zone, it has been determined from the cutting insert wear that the more the cutting speed increases, the more the tool wear, and increase in the tool wear causes poor surface roughness. In view of the outcomes of the cutting insert wear experiments, it has further been observed that CBN cutting insert is more resistant to wear than the ceramic insert, and that better surface roughness values have been obtained from the experiments performed by means of CBN cutting inserts.

\section{Acknowledgments}

The authors are pleased to acknowledge the financial support for this study from Karabük University Scientific Research Projects Department (KBÜ-BAP-17-YL-192). 


\section{References}

[1] S. Sen, I. Ozbek, U. Sen, C. Bindal, Surf. Coat. Technol. 135, 173 (2001).

[2] Ö.N. Cora, M. Koç, Int. J. Mach. Tools Manufact. 49, 897 (2009).

[3] G. Poulachon, A. Moisan, I.S. Jawahir, Wear 250 576 (2001).

[4] T. Özel, Y. Karpat, Int. J. Mach. Tools Manufact. 45, 467 (2005).

[5] Y. Matsumoto, F. Hashimoto, G. Lahoti, CIRP Ann. Manufact. Technol. 48, 59 (1999).

[6] X.L. Liu, D.H. Wen, Z.J. Li, L. Xiao, F.G. Yan, J. Mater. Process. Technol. 129, 217 (2002).

[7] H. Aouici, M.A. Yallese, K. Chaoui, T. Mabrouki, J.F. Rigal, Meas. J. Int. Meas. Confed. 45, 344 (2012).

[8] C. Lahiff, S. Gordon, P. Phelan, Robot. Comput. Integr. Manufact. 23, 638 (2007).

[9] R. Pavel, I. Marinescu, M. Deis, J. Pillar, J. Mater. Process. Technol. 170, 341 (2005).

[10] I. Meddour, M.A. Yallese, R. Khattabi, M. Elbah, L. Boulanouar, Int. J. Adv. Manufact. Technol. 77, 1387 (2015).
[11] V.N. Gaitonde, S.R. Karnik, L. Figueira, J. Paulo Davim, Int. J. Refract. Met. Hard Mater. 27, 754 (2009).

[12] B. Fnides, M.A. Yallese, Mechanics 70, 73 (2016).

[13] H. Aouici, H. Bouchelaghem, M.A. Yallese, M. Elbah, B. Fnides, Int. J. Adv. Manufact. Technol. 73, 1775 (2014).

[14] D.I. Lalwani, N.K. Mehta, P.K. Jain, J. Mater. Process. Technol. 206, 167 (2008).

[15] I. Asiltürk, H. Akkuş, Meas. J. Int. Meas. Confed. 44, 1697 (2011).

[16] M. Elbah, M.A. Yallese, H. Aouici, T. Mabrouki, J.F. Rigal, Meas. J. Int. Meas. Confed. 46, 3041 (2013).

[17] V.N. Gaitonde, S.R. Karnik, L. Figueira, J.P. Davim, Int. J. Refract. Met. Hard Mater. 27, 754 (2009).

[18] M.W. Azizi, S. Belhadi, M.A. Yallese, T. Mabrouki, J.F. Rigal, J. Mech. Sci. Technol. 26, 4105 (2012).

[19] M. Günay, E. Yücel, Meas. J. Int. Meas. Confed. 46, 913 (2013).

[20] S. Smith, S.N. Melkote, E. Lara-Curzio, T.R. Watkins, L. Allard, L. Riester, Mater. Sci. Eng. A 459, 337 (2007). 